\title{
Plywood Production Development Strategy at CV Alaf Denida
}

\author{
Alfina Taswirul Fanni \\ CV Alaf Denida \\ alfynataswirulfanni@gmail.com \\ https://doi.org/10.37715/rmbe.v1i2.2436
}

\begin{abstract}
CV Alaf Denida is a local wood-processing company located in Babat, Lamongan, East Java. CV Alaf Denida started their business in 2013 focused on fabrication in processing of sengon (albasia) into bare core as main material for blockboard production. The factory located in Desa Dradah Blumbang. Kecamatan Kedungpring, Kabupaten Lamongan. This research aims to make a design production development strategies at CV Alaf Denida by identifying internal and external factor of the company, analyzing alternative strategies of production development and recommending priority strategies which is used by CV Alaf Denida in developing the products. The research metode is a qualitative method with an intrinsic case study approach. The collecting data method used in this research done with observasion process, interview, and documentation. Analysis tools used for analyzing the data are IFE, EFE, SWOT, and QSPM matrix for showing the priority strategies. The validity test of this research using researcher triangulation, method, and resource data.
\end{abstract}

Keywords - CV Alaf Denida, Barecore, Intrinsic Case Study, IFE, EFE, SWOT, QSPM Matrix, Production Development Strategy.

\section{Introduction}

According to Winarto (2016) in his notes at IBCA (Indonesian Barecore Association), the bare core industry is one of the wood processing industries, bare core or pieces of wood arranged in the form of boards, namely semifinished materials for environmentally friendly furniture and wall products. The type of wood used as raw material for bare core is sengon, jabon or albasia wood. One of the local wood processing companies in Indonesia is CV Alaf Denida. The products manufactured by the company are bare core. Over time, CV Alaf Denida experienced fluctuating production results. In 2018, the realization of CV Alaf Denida's production has almost met the target, namely with a realization rate of $98.76 \%$, but in 2019 , the realization rate of production decreased significantly compared to the previous year, which was $81.08 \%$. This condition is a serious concern for the management of CV Alaf Denida to be addressed immediately so that in 2020 the level of realization of the production process will improve.

The decline in the production process can be caused by several factors. Assauri (2011) states that the production process is closely related to production factors, namely labor, capital, skills, raw materials and equipment and machinery. Pangestu (2013) added, the factors that cause a decline in production output are often referred to as 4M are labor (man), machines (machines), raw materials (materials), and methods (methods). However, in practice there is still the possibility of problems that hinder the production process with results that do not match the company's target.

\section{Literature Review}

\subsection{Previous Research}

Research by Gupta et al., (2015) the aim of this research is to develop the right strategy for a growing Indian Company. To achieve the research objectives, SWOT analysis along with QSPM and SPACE matrix was used using a qualitative approach with SWOT and QSPM analysis. This research resulted in the selection of strategies for departmental development and the proposed strategy is very useful for the industry because success is based on customization that aims to bring profits with the best quality and price.

The second previous study belongs to Saghaei et al., (2012) aims to assess the strengths, weaknesses, opportunities, and threats for the strategic development of food industry companies using a qualitative approach 
with SWOT analysis, QSPM, and the results show that the company is placed in an aggressive strategy area, then the results of the QSPM are strategies to increase international market share. get the highest score.

Research by Fitriandari et al., (2015) aims to analyze external factors in order to identify opportunities and threats for the Gramedia Duta Plaza Bookstore. The results of the study indicate that an adequate strategy to be implemented by the company in the future is growth and build strategy. This study also supports the author's research because it has relevance in analyzing the company's internal and external factors using the SWOT analysis method to find out the right business development strategy.

\subsection{Strategy and Strategic Management}

David (2012) explains the notion of strategy is a shared means with long-term goals to be achieved by the company. Stephanie (2002) reveals that strategy is a process of determining the plan of top leaders that focuses on the long-term goals of the organization, accompanied by the preparation of a method or effort how to achieve these goals. According to Daft (2006) strategic management is a collection of decisions and actions used in the preparation and implementation of strategies that will result in a superior competitive fit between the organization and its environment to achieve organizational goals. According to Hunger \& Wheelen (2003) strategic management is a series of managerial decisions and actions that determine the company's performance in the long term.

\subsection{Business Strategy}

According to Pádraig (2017) business strategy is also called competitive strategy, which includes offensive or defensive actions in order to create a secure position against competition. Broadly speaking, it includes a number of possible approaches:

1. Placing the company in a position so that it can provide the best defense against the existing set of competition.

2. Affects the balance of power through strategic moves and hence improves the relative position of the company.

3. Anticipating shifts in the factors that cause competitive forces and responding to them, so as to take advantage of the changes by choosing a strategy that fits the new competitive balance before the opponent is aware of it.

According to David (2012), the comprehensive strategic management model includes three stages of the process, namely strategy formulation, strategy implementation, and strategy evaluation, as well as feedback from each of these processes. David (2012) also reveals that the strategic management process results in decisions that have significant and long-term consequences. Wrong strategic decisions can lead to big losses. Therefore, the performance evaluation process is the final stage of the strategic management process which is no less important. Strategy evaluation includes three basic activities, namely:

1. Reviewing the foundation of the company's strategy,

2. Comparing the expected results with reality,

3. Take corrective action to ensure that performance is according to plan.

\subsection{Internal Environmental Analysis}

According to David (2012), internal strengths and weaknesses are controllable organizational activities that are run very well or very poorly. These internal factors arise in the management, marketing, finance or accounting, production or operations, research and development, and management information systems activities of a business.

\subsection{External Environmental Analysis}

According to David (2012) External forces can be divided into five broad categories: economic forces, social, cultural, demographic and environmental forces, political, legal, government, technological and competitive forces. Changes in external forces result in changes in consumer demand for industrial and consumer goods and services. External forces affect the type of product developed, the characteristics of the market segmentation and positioning strategy, the type of service offered, and the choice of business to be acquired or sold.

\subsection{EFE (External Factor Evaluation) and IFE (Internal Factor Evaluation) Matrix}

The IFE matrix is a strategy formulation tool that summarizes and evaluates the main strengths and weaknesses in the functional areas of the business, and also forms the basis for identifying and evaluating the relationships between these areas. The EFE Matrix is a tool that enables strategic planners to summarize and evaluate 
economic, socio-cultural, environmental, political, government, legal, technological and competitive information. This matrix helps managers in organizing external strategic factors into generally accepted categories of opportunities and threats David (2012).

\section{7. $\quad$ SWOT Matrix (Strengths, Weaknesses, Opportunities, Threats)}

According to David (2012), the matrix of strengths, weaknesses, opportunities and threats is an important matching tool that helps managers develop four types of strategies: SO Strategy (Strengths-Opportunities), WO Strategy (Weakness-Opportunities), ST Strategy (Strengths-Opportunities). Threats), and WT (Weakness-Threats) Strategy.

\subsection{QSPM Matrix (Qualitative Strategic Planning Matrix)}

The QSPM (Quantitative Strategic Planning Matrix) matrix is an analytical technique in the literature designed to determine the relative attractiveness of alternative actions that can be implemented David (2012). Conceptually, QSPM determines the relative attractiveness of various strategies based on the extent to which key external and internal critical success factors are utilized or improved. The relative attractiveness of each strategy is calculated by determining the cumulative impact of each of the external and internal crisis success factors. A positive trait of QSPM is that these sets of strategies can be examined sequentially or concurrently. This tool also requires strategic planners to incorporate relevant internal and external factors into the decision process.

\subsection{Alternative Strategy}

According to Schroeder (2007), one of the strategies companies can choose is the production or operation strategy. Operations Strategy is a set of objectives, plans, and policies that describe how the operations function supports the company's business strategy. Schroeder (2007) states that operating strategy is a description of business/corporate strategy, so that the five categories of decisions described above can be taken accurately and consistently. Thus, the operations strategy will provide a direction for making decisions. Schroeder (2007) also suggests that external and internal analysis are inputs in formulating operating strategies and business strategies. External analysis is directed at identifying opportunities and threats to the company's operations due to changes in factors from the external environment, such as competition, economy, technology, information, politics, consumer demands, disruption of raw material supply, government regulations/regulations, culture, and social conditions. . The real external environment that has occurred in the era of globalization in 2000 , is the sharp level of competition as a result of free trade or market globalization.

\section{Research Methods}

\subsection{Analysis Model}

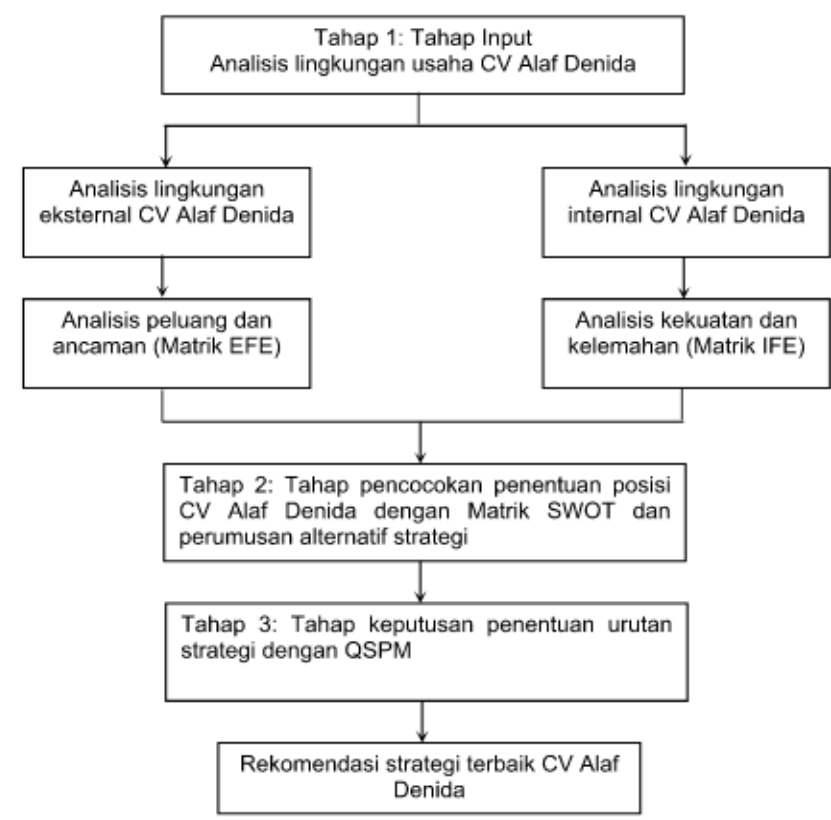

Figure 3.1. Analysis Model Source: Data processed (2020) 


\subsection{Research Approach}

Methods the research will be conducted using qualitative research methods with an intrinsic case study approach. Case study is research that can better understand a particular case to the fullest. Intrinsic case studies are carried out because they want to understand intrinsically, the regularity and specificity of the case, not externally. The following are the stages of the case study process:

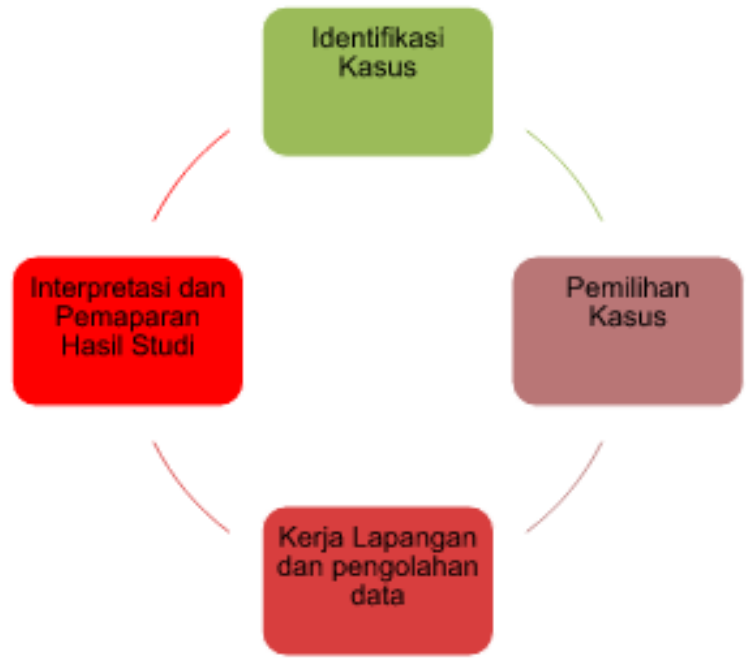

Figure 3.2. Case study process

Source: Wirawan (2020)

The resource persons in this study, the researchers determined by purposive sampling method. Purposive sampling is a sampling technique (resources) with certain considerations (David, 2012). This study uses purposive sampling with the hope that the sources obtained are truly in accordance with the research conducted and are able to explain the actual situation about the object under study. The subjects that will be used as research resources are business people, competitors/partners, and experts in the field of marketing.

\section{Result and Discussion}

\subsection{Business Environment Analysis CV. Alaf Denida}

Based on the results of interviews with informants, there are 14 factors that have been identified in the external environment in CV Alaf Denida. The fourteen factors come from raw materials, suppliers, legality, market/buyers, modernization developments, banking, and competitors. After listing the main factors that have an important impact (critical success factors) for the company's internal (strengths and weaknesses) and external (opportunities and threats) aspects, then calculate the weight of each factor with the following assessment previously carried out:

Number 4 = very important;

Number 3 = important;

Number 2 = less important;

Number $1=$ not important;

Tabel 4.1. Results of the Weighting of External and Internal Strategy Factors

\begin{tabular}{|c|c|c|c|c|c|c|}
\hline \multirow{2}{*}{ No } & \multirow{2}{*}{ Internal and External Factors } & \multicolumn{3}{|c|}{ Level of Interest } & \multirow{2}{*}{ Average } & \multirow{2}{*}{ Weight } \\
\hline & & Owner & Supplier & Expert & & \\
\hline 1 & $\begin{array}{l}\text { The position of the company in Babat } \\
\text { Lamongan }\end{array}$ & 3 & 2 & 2 & 2.3 & 0.023 \\
\hline 2 & $\begin{array}{l}\text { The position of the company in the } \\
\text { countryside }\end{array}$ & 3 & 3 & 3 & 3.0 & 0.030 \\
\hline 3 & Quality and quantity of workforce owned & 4 & 4 & 4 & 4.0 & 0.040 \\
\hline 4 & $\begin{array}{l}\text { Availability of machinery and supporting } \\
\text { equipment }\end{array}$ & 4 & 4 & 4 & 4.0 & 0.040 \\
\hline 5 & Employee work ethic & 3 & 4 & 4 & 3.7 & 0.036 \\
\hline 6 & Owned engine performance & 4 & 4 & 4 & 4.0 & 0.040 \\
\hline 7 & Pro-active attitude of employees & 3 & 3 & 3 & 3.0 & 0.030 \\
\hline
\end{tabular}




\begin{tabular}{|c|c|c|c|c|c|c|}
\hline 8 & Machine maintenance & 4 & 4 & 4 & 4.0 & 0.040 \\
\hline 9 & Payment system to suppliers & 3 & 3 & 3 & 3.0 & 0.030 \\
\hline 10 & Ease of purchasing products by buyers & 4 & 4 & 4 & 4.0 & 0.040 \\
\hline 11 & Company's financial condition & 4 & 3 & 4 & 3.7 & 0.036 \\
\hline 12 & Technology support & 4 & 4 & 4 & 4.0 & 0.040 \\
\hline 13 & Decision making system & 3 & 3 & 3 & 3.0 & 0.030 \\
\hline 14 & Management information System & 3 & 4 & 3 & 3.3 & 0.033 \\
\hline 15 & Price & 4 & 4 & 4 & 4.0 & 0.040 \\
\hline 16 & Availability of raw materials & 4 & 3 & 4 & 3.7 & 0.036 \\
\hline 17 & Standardization of raw material quality & 4 & 4 & 4 & 4.0 & 0.040 \\
\hline 18 & Raw material delivery speed & 4 & 4 & 4 & 4.0 & 0.040 \\
\hline 19 & $\begin{array}{l}\text { Conformity of raw material specifications } \\
\text { with orders }\end{array}$ & 4 & 4 & 4 & 4.0 & 0.040 \\
\hline 20 & Relationship with raw material suppliers & 4 & 3 & 3 & 3.3 & 0.033 \\
\hline 21 & Company legality & 4 & 3 & 3 & 3.3 & 0.033 \\
\hline 22 & Wood waste management system & 3 & 4 & 3 & 3.3 & 0.033 \\
\hline 23 & Market globalization & 3 & 3 & 3 & 3.0 & 0.030 \\
\hline 24 & Technological development & 3 & 4 & 3 & 3.3 & 0.033 \\
\hline 25 & Machine modernization development & 3 & 3 & 3 & 3.0 & 0.030 \\
\hline 26 & $\begin{array}{l}\text { Economic growth and market purchasing } \\
\text { power }\end{array}$ & 3 & 3 & 3 & 3.0 & 0.030 \\
\hline 27 & Funding support from banks & 3 & 3 & 3 & 3.0 & 0.030 \\
\hline 28 & $\begin{array}{l}\text { Competitive situation of competitors/ } \\
\text { similar companies }\end{array}$ & 3 & 3 & 3 & 3.0 & 0.030 \\
\hline 29 & Buyer loyalty level & 4 & 4 & 4 & 4.0 & 0.040 \\
\hline & & \multicolumn{3}{|c|}{ Amount } & 101,0 & 1 \\
\hline
\end{tabular}

Source: Data processed (2020)

\subsection{IFE (Internal Factor Evaluation) Matrix}

The IFE matrix is used to identify internal environmental factors and classify them into company strengths and weaknesses through the results of pre-calculated weighting and rating on each factor. The rating (rating) by each resource person on each of these factors is assessed by providing the following assessment options:

Number 4 = very strong;

Number 3 = strong;

Number 2 = weak;

Number 1 = very weak;

Tabel 4.2. Internal Factor Evaluation Results

\begin{tabular}{|c|c|c|c|c|c|c|c|c|}
\hline \multirow{2}{*}{ No } & \multirow{2}{*}{ Internal factors } & \multicolumn{3}{|c|}{ Evaluation } & \multirow{2}{*}{ Weight } & \multirow{2}{*}{ Rating } & \multirow{2}{*}{$\begin{array}{l}\text { Weight } \\
\text { x Rating }\end{array}$} & \multirow{2}{*}{ Criteria } \\
\hline & & Owner & Manager & Staff & & & & \\
\hline 1 & $\begin{array}{l}\text { The position of the company in } \\
\text { Babat Lamongan }\end{array}$ & 2 & 3 & 3 & 0.023 & 2.7 & 0.062 & W \\
\hline 2 & $\begin{array}{l}\text { The position of the company in } \\
\text { the countryside }\end{array}$ & 4 & 3 & 4 & 0.030 & 3.7 & 0.109 & S \\
\hline 3 & $\begin{array}{l}\text { Quality and quantity of workforce } \\
\text { owned }\end{array}$ & 2 & 2 & 3 & 0.040 & 2.3 & 0.092 & $\mathrm{~W}$ \\
\hline 4 & $\begin{array}{l}\text { Availability of machinery and } \\
\text { supporting equipment }\end{array}$ & 4 & 4 & 3 & 0.040 & 3.7 & 0.145 & $S$ \\
\hline 5 & Employee work ethic & 2 & 2 & 3 & 0.036 & 2.3 & 0.085 & $\mathrm{~W}$ \\
\hline 6 & Owned engine performance & 2 & 2 & 3 & 0.040 & 2.3 & 0.092 & $\mathrm{~W}$ \\
\hline 7 & Pro-active attitude of employees & 3 & 3 & 4 & 0.030 & 3.3 & 0.099 & $S$ \\
\hline 8 & Machine maintenance & 1 & 2 & 2 & 0.040 & 1.7 & 0.066 & $\mathrm{~W}$ \\
\hline 9 & Payment system to suppliers & 3 & 4 & 3 & 0.030 & 3.3 & 0.099 & $S$ \\
\hline 10 & $\begin{array}{l}\text { Ease of purchasing products by } \\
\text { buyers }\end{array}$ & 4 & 3 & 3 & 0.040 & 3.3 & 0.132 & $S$ \\
\hline
\end{tabular}




\begin{tabular}{|c|c|c|c|c|c|c|c|c|}
\hline 11 & Company's financial condition & 3 & 3 & 3 & 0.036 & 3.0 & 0.109 & $\mathrm{~S}$ \\
\hline 12 & Technology support & 2 & 3 & 2 & 0.040 & 2.3 & 0.092 & $\mathrm{~W}$ \\
\hline 13 & Decision making system & 2 & 3 & 2 & 0.030 & 2.3 & 0.069 & $\mathrm{~W}$ \\
\hline 14 & Management information System & 1 & 3 & 2 & 0.033 & 2.0 & 0.066 & W \\
\hline 15 & Price & 3 & 3 & 3 & 0.040 & 3.0 & 0.119 & $\mathrm{~S}$ \\
\hline & & \multicolumn{5}{|c|}{ Benchmark } & 0,096 & \\
\hline
\end{tabular}

Source: Data processed (2020)

Based on the calculation, it is known that the benchmark value or the average of all internal factors is 0.096 . These internal factors are then divided into two parts, namely internal factors whose average value is above the benchmark value, grouped as Strengths, and internal factors whose average value is below the benchmark value, which are grouped as Weaknesses.

\subsection{EFE (External Factor Evaluation) Matrix}

The EFE matrix is used to identify external environmental factors and classify them into opportunities and threats to the company through the results of pre-calculated weighting and rating on each factor. The rating (rating) by each resource person on each of these factors is assessed by providing the following assessment options:

Number 4 = very high;

Number 3 = height;

Number 2 = low;

Number 1 = very low;

Table 4.4. External Factor Evaluation Results

\begin{tabular}{|c|c|c|c|c|c|c|c|c|}
\hline \multirow{2}{*}{ No } & \multirow{2}{*}{ External Factors } & \multicolumn{3}{|c|}{ Evaluation } & \multirow{2}{*}{ Weight } & \multirow{2}{*}{ Rating } & \multirow{2}{*}{$\begin{array}{l}\text { Weight } \\
\text { x Rating }\end{array}$} & \multirow{2}{*}{ Criteria } \\
\hline & & Owner & Buyer & Expert & & & & \\
\hline 1 & Availability of raw materials & 2 & 2 & 3 & 0.036 & 2.3 & 0.085 & $\mathrm{~T}$ \\
\hline 2 & $\begin{array}{l}\text { Standardization of raw material } \\
\text { quality }\end{array}$ & 1 & 2 & 2 & 0.040 & 1.7 & 0.066 & $\mathrm{~T}$ \\
\hline 3 & Raw material delivery speed & 2 & 2 & 2 & 0.040 & 2.0 & 0.079 & $\mathrm{~T}$ \\
\hline 4 & $\begin{array}{l}\text { Conformity of raw material } \\
\text { specifications with orders }\end{array}$ & 2 & 2 & 2 & 0.040 & 2.0 & 0.079 & $\mathrm{~T}$ \\
\hline 5 & $\begin{array}{l}\text { Relationship with raw material } \\
\text { suppliers }\end{array}$ & 3 & 3 & 3 & 0.033 & 3.0 & 0.099 & $\mathrm{O}$ \\
\hline 6 & Company legality & 4 & 4 & 3 & 0.033 & 3.7 & 0.121 & $\mathrm{O}$ \\
\hline 7 & Wood waste management system & 2 & 3 & 1 & 0.033 & 2.0 & 0.066 & $\mathrm{~T}$ \\
\hline 8 & Market globalization & 3 & 3 & 3 & 0.030 & 3.0 & 0.089 & $\mathrm{O}$ \\
\hline 9 & Technological development & 3 & 3 & 3 & 0.033 & 3.0 & 0.099 & $\mathrm{O}$ \\
\hline 10 & $\begin{array}{l}\text { Machine modernization } \\
\text { development }\end{array}$ & 3 & 3 & 4 & 0.030 & 3.3 & 0.099 & $\mathrm{O}$ \\
\hline 11 & $\begin{array}{l}\text { Economic growth and market } \\
\text { purchasing power }\end{array}$ & 2 & 1 & 2 & 0.030 & 1.7 & 0.050 & $\mathrm{~T}$ \\
\hline 12 & Funding support from banks & 3 & 3 & 4 & 0.030 & 3.3 & 0.099 & $\mathrm{O}$ \\
\hline 13 & $\begin{array}{l}\text { Competitive situation of } \\
\text { competitors/ similar companies }\end{array}$ & 3 & 2 & 3 & 0.030 & 2.7 & 0.079 & $\mathrm{~T}$ \\
\hline \multirow[t]{2}{*}{14} & Buyer loyalty level & 3 & 4 & 3 & 0.040 & 3.3 & 0.132 & $\mathrm{O}$ \\
\hline & & \multicolumn{5}{|c|}{ Benchmark } & 0,089 & \\
\hline
\end{tabular}

Source: Data processed (2020)

Based on the calculation, it is known that the benchmark value or the average of all external factors is 0.089. These external factors are then divided into two parts, namely external factors whose average value is above the benchmark value, grouped as Opportunities, and external factors whose average value is below the benchmark value, which are grouped as Threats.

\subsection{SWOT Matrix}

To find out the priority results and the interrelationships between strategies based on the SWOT matrix, a combination of internal-external strategies was carried out. The formulation of these strategies is based on internal factors, strengths and weaknesses, as well as external opportunities and threats that have been described and then 
entered into the SWOT Matrix. Strength and weakness factors are placed in the first row, and opportunity and threat factors are placed in the first column, then the intersection between rows and columns is formed by 4 cells, which can be the intersection of $\mathrm{S}$ and $\mathrm{O}, \mathrm{S}$ and $\mathrm{T}, \mathrm{W}$ and $\mathrm{O}$, and $\mathrm{W} \& \mathrm{~T}$.

Table 4.5. SWOT Matrix

\begin{tabular}{|c|c|c|}
\hline EFAS \& IFAS & $\begin{array}{l}\text { Strength (S) } \\
\text { a. The position of the company in the } \\
\text { countryside } \\
\text { b. Availability of machinery and } \\
\text { supporting equipment } \\
\text { c. Pro-active attitude of employees } \\
\text { d. Payment system to suppliers } \\
\text { e. Ease of purchasing products by } \\
\text { buyers } \\
\text { f. Company's financial condition } \\
\text { g. Price }\end{array}$ & $\begin{array}{l}\text { Weaknesses (W) } \\
\text { a. The position of the company in } \\
\text { Babat Lamongan } \\
\text { b.Quality and quantity of workforce } \\
\text { owned } \\
\text { c. Employee work ethic } \\
\text { d. Owned engine performance } \\
\text { e. Machine maintenance } \\
\text { f. Technology support } \\
\text { g. Decision making system } \\
\text { h.Management information System }\end{array}$ \\
\hline $\begin{array}{l}\text { Opportunities }(\mathbf{O}) \\
\text { a. Relationship with raw } \\
\text { material suppliers } \\
\text { b. } \text { Company legality } \\
\text { c. Market globalization } \\
\text { d. Technological development } \\
\text { e. Machine modernization } \\
\text { development } \\
\text { f. Funding support from banks } \\
\text { g. Buyer loyalty level }\end{array}$ & $\begin{array}{l}\text { SO Strategy } \\
\text { 1. Good relations with suppliers must } \\
\text { be maintained by continuing to } \\
\text { provide convenience in the } \\
\text { payment system, namely by } \\
\text { continuing to buy goods that do not } \\
\text { meet specifications at prices that } \\
\text { have been adjusted. } \\
\text { 2. Market globalization and high } \\
\text { technological developments can be } \\
\text { an opportunity for companies } \\
\text { because companies already have } \\
\text { adequate tools and make it easier } \\
\text { for buyers to transact with } \\
\text { companies. } \\
\text { 3. Good support from banks must be } \\
\text { maintained to keep the company's } \\
\text { finances and capital sufficient } \\
\text { 4. Loyal buyers must be maintained by } \\
\text { providing ease of purchase and } \\
\text { providing competitive prices }\end{array}$ & $\begin{array}{l}\text { WO Strategy } \\
\text { 5. The company's position in the region } \\
\text { becomes an obstacle when it } \\
\text { requires machine maintenance or } \\
\text { buying machine spare parts. Stock } \\
\text { needs to be done so that the } \\
\text { production process is not disrupted, } \\
\text { because the company's funding is } \\
\text { also sufficient } \\
\text { 6. The rapid development of technology } \\
\text { is not accompanied by } \\
\text { modernization of machines, due to } \\
\text { the unprepared workforce and low } \\
\text { work ethic, the scheduling } \\
\text { of machine maintenance is also not } \\
\text { regular causing machine } \\
\text { performance not optimal. } \\
\text { 7. The potential of market globalization } \\
\text { can only be achieved if the } \\
\text { company's decision-making system } \\
\text { does not only rely on the owner, but } \\
\text { there must be a system, and also } \\
\text { improve the company's management } \\
\text { information system so that } \\
\text { information can be more } \\
\text { synchronized between parts, so that } \\
\text { the production process can be } \\
\text { optimal, the impact of buyer loyalty } \\
\text { can be maintained }\end{array}$ \\
\hline $\begin{array}{l}\text { Threats }(\mathbf{T}) \\
\text { a. Availability of raw materials } \\
\text { b. Standardization of raw } \\
\text { material quality } \\
\text { c. Raw material delivery speed } \\
\text { d.Conformity of raw material } \\
\text { specifications with orders } \\
\text { e. Wood waste management } \\
\text { system } \\
\text { f. Economic growth and market } \\
\text { purchasing power } \\
\text { g. Competitive situation of } \\
\text { competitors/ similar } \\
\text { companies }\end{array}$ & $\begin{array}{l}\text { ST strategy } \\
\text { 8. The company's position in rural } \\
\text { areas, of course, must provide } \\
\text { convenience in processing wood } \\
\text { waste so as not to disturb the } \\
\text { environment } \\
\text { 9. The non-standard quality of raw } \\
\text { materials must be overcome by } \\
\text { product innovation, the application } \\
\text { of telly, and a flexible payment } \\
\text { system, namely continuing to } \\
\text { accept down grade goods at lower } \\
\text { prices. } \\
\text { 10. Economic recession conditions } \\
\text { cause purchasing power to fall, so } \\
\text { companies must maintain } \\
\text { relationships with suppliers and }\end{array}$ & $\begin{array}{l}\text { WT Strategy } \\
\text { 11. Upgrade machine performance } \\
\text { with routine maintenance and } \\
\text { improve the quality of the workforce } \\
\text { with an improved work ethic, in } \\
\text { order to be able to manage the } \\
\text { remaining yield of raw materials } \\
\text { into downgrade products and so that } \\
\text { machine rips are not often hampered, } \\
\text { because wood raw materials of non- } \\
\text { standard size require optimal } \\
\text { machine performance } \\
\text { 12. Start studying technology support in } \\
\text { the company's business management } \\
\text { so that it can be a solution in times } \\
\text { of economic recession and declining } \\
\text { purchasing power, because }\end{array}$ \\
\hline
\end{tabular}




\begin{tabular}{|l|l|l|}
\hline & $\begin{array}{l}\text { buyers, by giving discounts or late } \\
\text { payments }\end{array}$ & $\begin{array}{l}\text { technology can reduce company } \\
\text { operating costs, as well as improve } \\
\text { management information systems so } \\
\text { that decisions can be taken more } \\
\text { quickly and accurately, in times of } \\
\text { intense competition. start a bit }\end{array}$ \\
& & \\
\hline
\end{tabular}

\subsection{QSPM Matrix}

The QSPM matrix is compiled by first compiling a list of strengths, weaknesses, opportunities and threats and then assigning weights, then alternative strategies are compiled and evaluated by setting attractiveness scores (AS) ranging from 1 to 4 . Value $1=$ not attractive, $2=$ somewhat attractive, $3=$ moderately attractive, $4=$ very attractive, and if there is no effect on the alternative strategy being considered then no value is given (AS). After that, the total attractiveness score (Total Attractiveness Scores - TAS) is calculated, then multiplying the weight by the attractiveness value (AS), produces the total number of attractiveness scores. The alternative strategy that has the largest total value is the best strategy. The QSPM matrix was developed through 12 alternative strategies, so that the company was able to evaluate and then choose the best and most suitable strategies for the company's internal conditions and the external environment.

Table 4.5. QSPM Matrix

\begin{tabular}{|c|c|c|c|c|c|c|c|c|c|}
\hline \multirow{3}{*}{$\begin{array}{c}\text { Strategy } \\
\text { Success } \\
\text { Factor }\end{array}$} & \multirow{3}{*}{ Weight } & \multicolumn{8}{|c|}{ Alternative Strategy } \\
\hline & & \multicolumn{2}{|c|}{ No.9 } & \multicolumn{2}{|c|}{ No. 10} & \multicolumn{2}{|c|}{ No.11 } & \multicolumn{2}{|c|}{ No. 12} \\
\hline & & AS & TAS & AS & TAS & AS & TAS & AS & TAS \\
\hline \multicolumn{10}{|c|}{ Internal factors } \\
\hline 1 & 0,023 & 2 & 0.0 & 2 & 0.0 & 2 & 0.0 & 2 & 0.0 \\
\hline 2 & 0,030 & 2 & 0.1 & 2 & 0.1 & 2 & 0.1 & 2 & 0.1 \\
\hline 3 & 0,040 & 4 & 0.2 & 2 & 0.1 & 4 & 0.2 & 2 & 0.1 \\
\hline 4 & 0,040 & 3 & 0.1 & 2 & 0.1 & 4 & 0.2 & 2 & 0.1 \\
\hline 5 & 0,036 & 4 & 0.1 & 2 & 0.1 & 3 & 0.1 & 3 & 0.1 \\
\hline 6 & 0,040 & 2 & 0.1 & 2 & 0.1 & 4 & 0.2 & 2 & 0.1 \\
\hline 7 & 0,030 & 3 & 0.1 & 2 & 0.1 & 3 & 0.1 & 3 & 0.1 \\
\hline 8 & 0,040 & 2 & 0.1 & 2 & 0.1 & 4 & 0.2 & 2 & 0.1 \\
\hline 9 & 0,030 & 4 & 0.1 & 3 & 0.1 & 2 & 0.1 & 3 & 0.1 \\
\hline 10 & 0,040 & 3 & 0.1 & 3 & 0.1 & 2 & 0.1 & 3 & 0.1 \\
\hline 11 & 0,036 & 2 & 0.1 & 3 & 0.1 & 3 & 0.1 & 3 & 0.1 \\
\hline 12 & 0,040 & 2 & 0.1 & 2 & 0.1 & 4 & 0.2 & 2 & 0.1 \\
\hline 13 & 0,030 & 2 & 0.1 & 2 & 0.1 & 2 & 0.1 & 3 & 0.1 \\
\hline 14 & 0,033 & 2 & 0.1 & 3 & 0.1 & 2 & 0.1 & 2 & 0.1 \\
\hline 15 & 0,040 & 3 & 0.1 & 3 & 0.1 & 3 & 0.1 & 3 & 0.1 \\
\hline \multicolumn{10}{|c|}{ External Factors } \\
\hline 1 & 0,036 & 4 & 0.1 & 2 & 0.1 & 4 & 0.1 & 2 & 0.1 \\
\hline 2 & 0,040 & 4 & 0.2 & 2 & 0.1 & 4 & 0.2 & 2 & 0.1 \\
\hline 3 & 0,040 & 2 & 0.1 & 3 & 0.1 & 4 & 0.2 & 2 & 0.1 \\
\hline 4 & 0,040 & 4 & 0.2 & 3 & 0.1 & 4 & 0.2 & 3 & 0.1 \\
\hline 5 & 0,033 & 2 & 0.1 & 4 & 0.1 & 4 & 0.1 & 2 & 0.1 \\
\hline 6 & 0,033 & 2 & 0.1 & 2 & 0.1 & 2 & 0.1 & 2 & 0.1 \\
\hline 7 & 0,033 & 2 & 0.1 & 2 & 0.1 & 3 & 0.1 & 2 & 0.1 \\
\hline 8 & 0,030 & 2 & 0.1 & 3 & 0.1 & 3 & 0.1 & 4 & 0.1 \\
\hline 9 & 0,033 & 2 & 0.1 & 3 & 0.1 & 4 & 0.1 & 4 & 0.1 \\
\hline
\end{tabular}




\begin{tabular}{|c|c|c|c|c|c|c|c|c|c|}
\hline 10 & 0,030 & 3 & 0.1 & 3 & 0.1 & 4 & 0.1 & 3 & 0.1 \\
\hline 11 & 0,030 & 2 & 0.1 & 3 & 0.1 & 2 & 0.1 & 2 & 0.1 \\
\hline 12 & 0,030 & 2 & 0.1 & 3 & 0.1 & 4 & 0.1 & 2 & 0.1 \\
\hline 13 & 0,030 & 2 & 0.1 & 2 & 0.1 & 3 & 0.1 & 3 & 0.1 \\
\hline 14 & 0,040 & 2 & 0.1 & 4 & 0.2 & 3 & 0.1 & 2 & 0.1 \\
\hline Total & 1,000 & & 2.62 & & 2.55 & & 3.23 & & 2.47 \\
\hline
\end{tabular}

Based on the QSPM matrix table above, it can be seen that four alternative strategies were found to be feasible to continue. The four alternative strategies with high total attractiveness scores, which are above the overall TAS average and deserve to be continued, the alternative strategies are:

Alternative strategy number 11 : The company upgrades the engine performance by carrying out routine and neatly scheduled maintenance, so that the engine rip is not often hampered, because wood raw materials of nonstandard size require optimal engine performance. In addition, it also improves the skills of the workforce so that they can manage the remaining yield of raw materials into downgrade products.

Alternative strategy number 9: Innovate products with a good employee work ethic due to the non-standard quality of raw materials. In addition, it also implements telly, which is payments to suppliers based on the grade of raw materials sent with a flexible payment system, namely still receiving down grade goods with lower price offers, so that they are mutually beneficial.

Alternative strategy number 10: Economic recession causes the market's purchasing power to decline, so companies must maintain good relations with suppliers and buyers, by giving discounts or late payments. In addition, it is necessary to develop new markets (add buyers) so that production capacity can be maintained even in conditions of economic recession.

Alternative strategy number 12: Start studying technology support in the company's business management so that it can be a solution during an economic recession and declining purchasing power, because technology can reduce company operating costs, and improve management information systems so that decisions can be taken more quickly and accurately. in times of intense competition.

\section{Conclusions and Practical Implication}

\subsection{Conclusion}

Based on the results of the analysis and discussion that have been described in the previous chapter, to solve the problem of the production target of CV Alaf Denida which is not met by designing a production development strategy at CV Alaf Denida is to maintain and repair the engine on a regular and scheduled basis to maintain optimal engine performance, improve the skills of the workforce so that they can manage the remaining yield of raw materials into derivative products that are still feasible, carry out product innovation by making quality goods even with different grades of raw materials, maintain production capacity by developing new market shares, begin to study technological support in managing the company's business to be more efficient when the economic recession and purchasing power decline, next is to build a management information system so that management decisions can be taken more quickly, precisely, and independently not depending on the owner.

\subsection{Practical Implication}

Table 5.1. Managerial Implications

\begin{tabular}{|c|l|l|}
\hline $\begin{array}{c}\text { Production } \\
\text { Development Strategy }\end{array}$ & \multicolumn{1}{c|}{ Present condition } & \multicolumn{1}{c|}{ Recommendation } \\
\hline Machine & $\begin{array}{l}\text { Machine maintenance is not } \\
\text { scheduled, only done when there } \\
\text { is damage or replacement } \\
\text { of spare parts. }\end{array}$ & $\begin{array}{l}\text { Machine maintenance is carried out regularly every weekend, } \\
\text { namely cleaning and adding oil to several parts. This is done } \\
\text { so that the engine performance upgrade can be more optimal, } \\
\text { so it is hoped that the machine rip is not often hampered, } \\
\text { because wood raw materials of non-standard size often } \\
\text { interfere with machine performance with wood chips scattered } \\
\text { during the cutting process. }\end{array}$ \\
\hline Labor & $\begin{array}{l}\text { The number of workers is } \\
\text { limited with skills that are still } \\
\text { not good with a work ethic that } \\
\text { is still low }\end{array}$ & $\begin{array}{l}\text { Improving the skills of the workforce by holding in-house } \\
\text { training (inside the room) and accidental training (when the } \\
\text { machine breaks down). The trainers are expert employees, } \\
\text { while the participants are other employees, this is done to } \\
\text { evenly distribute skills and the regeneration process, it is also }\end{array}$ \\
\hline
\end{tabular}




\begin{tabular}{|c|c|c|}
\hline & & $\begin{array}{l}\text { done so that the production quality is more optimal and } \\
\text { efficient by utilizing the remaining super yields } \\
\text { into downgrade derivative products. }\end{array}$ \\
\hline Product innovation & $\begin{array}{l}\text { Product innovation has not been } \\
\text { carried out, the remaining wood } \\
\text { yield is usually only used as } \\
\text { firewood }\end{array}$ & $\begin{array}{l}\text { Conduct product innovation accompanied by a high employee } \\
\text { work ethic by presenting selected products according to the } \\
\text { quality of raw materials, namely Grade Super, Grade A, Grade } \\
\text { B, All Grade, Balken 56, and Ampulur }\end{array}$ \\
\hline Raw material & $\begin{array}{l}\text { Non-standard raw materials } \\
\text { complicate the sorting and } \\
\text { grading process }\end{array}$ & $\begin{array}{l}\text { Standardizing raw materials is difficult, because they are } \\
\text { natural products with different cubications. The quality of raw } \\
\text { materials is also the main key in the barcore industry. For this } \\
\text { reason, the payment system for raw materials to suppliers is } \\
\text { not based on total weight, but is also adjusted to the cubication } \\
\text { of raw materials that produce different grades. The lower the } \\
\text { cubication, the lower the grade and the lower the cost. This } \\
\text { can be mutually beneficial for both parties, both the company } \\
\text { and the supplier. For companies, the remaining yield can be } \\
\text { suppressed and for suppliers of raw materials it can be sold }\end{array}$ \\
\hline $\begin{array}{l}\text { Relationship with } \\
\text { partners }\end{array}$ & $\begin{array}{l}\text { The supplier payment scheme is } \\
\text { carried out } 2 \mathrm{x}, \mathrm{DP} \text { and } \\
\text { repayment after the raw } \\
\text { materials are received. The } \\
\text { payment scheme by the buyer is } \\
\text { also done } 2 \mathrm{x} \text {, a down payment } \\
\text { and a month later when the } \\
\text { product has been shipped }\end{array}$ & $\begin{array}{l}\text { Economic recession conditions cause the purchasing power of } \\
\text { the market to decline, so companies must maintain good } \\
\text { relations with suppliers and buyers. Maintaining relationships } \\
\text { with suppliers is done by paying back so that both can run, the } \\
\text { supplier of goods is sold and the company can also } \\
\text { operate. While maintaining relationships with buyers by } \\
\text { giving discounts or payments in installments for } 3 \text { months } \\
\text { after the goods are received by the buyer }\end{array}$ \\
\hline Technology support & $\begin{array}{l}\text { There is no technology support } \\
\text { on the company's management } \\
\text { system }\end{array}$ & $\begin{array}{l}\text { Technological developments in machines are indeed low, } \\
\text { because they have been like that for decades, and also because } \\
\text { the company's products are semi-finished } \\
\text { products. Technology can be used in production information } \\
\text { management systems, because technology can reduce } \\
\text { operational costs, as well as improve management information } \\
\text { systems so that decisions can be made faster and more } \\
\text { accurately, when the competition situation is getting tougher. }\end{array}$ \\
\hline
\end{tabular}

Source: Data processed (2020)

\section{References}

Assauri, S. (2011). Manajemen pemasaran. Jakarta: Rajawali Pers.

Daft, R. L. (2006). Manajemen. Buku 1, Alih bahasa oleh Edward Tanujaya dan Shirly Tiolina (Edisi ke-6). Salemba Empat.

David, F. R. (2012). Strategic management: Manajemen strategis: Konsep (Buku 1) (Edisi 12). Salemba Empat.

Fitriandari, M., Sukaatmadja, I. P., \& Giantari, I. G. A. (2015). Analisis strategi bisnis pada Toko Buku Gramedia

Duta Plaza di Kota Denpasar. E-Jurnal Ekonomi Dan Bisnis Universitas Udayana, 4(3), 163-182. https://ojs.unud.ac.id/index.php/EEB/article/view/11810

Gupta, M., Shri, C., \& Agrawal, A. (2015). Strategy formulation for performance improvement of indian corrugated industry: An application of SWOT analysis and QSPM Matrix. Journal of Applied Packaging Research, 7(3), 60-75.

Hunger, D. J., \& Wheelen, T. L. (2003). Manajemen Strategis. Yogyakarta: Andi.

Pádraig, B. (2017). An Analysis of Michael E. Porter's Competitive Strategy Techniques for Analyzing Industries and Competitors. Macat Library. https://doi.org/10.4324/9781912281060

Pangestu, S. (2013). Forecasting konsep dan aplikasi (Edisi Keti). Yogyakarta: BPFE-Yogyakarta.

Saghaei, M., Fazayeli, L., \& Shojaee, M. R. (2012). Strategic planning for a lubricant manufacturing company using SWOT analysis, QSPM Model (One of the top companies of Iranian oil, gas and petrochemical products exporters' association). Australian Journal of Business and Management Research, 01(10), 18-24. https://doi.org/10.52283/NSWRCA.AJBMR.20120110A03

Schroeder, R. G. (2007). Operations management: Contemporary concepts and cases. Boston : McGraw-Hill/Irwin. Stephanie, K. M. (2002). Desain penelitian manajemen strategik. Jakarta: Rajawali Press.

Winarto, Y. (2016). IBcA: Pasar menjanjikan bagi industri barecore. https://industri.kontan.co.id/news/ibca-pasarmenjanjikan-bagi-industri-barecore 